\title{
Representation as repression: A First Peoples context
}

\author{
Roie Thomas
}

\begin{abstract}
Visual images of a marginalised minority group from southern Africa are analysed against a series of colonialist representations to demonstrate tangible evidence of the role of representation in both disenfranchisement and an increasing autonomy in the case of the San, who are The First Peoples of the Kalahari, commonly known outside Africa as 'Bushmen' and in the dominant language of Botswana as Basarwa. This particular group is represented by government and its corporate affiliates as primordial for tourist consumption, yet systemically denied their language, ethnicity and ancestral land. Analysis is supported by critical tourism literature, showing the attitudes, power dynamics and practices evident in the produced imagery. An overview of the theoretical enframing and methodology is followed by analysis of a range of visual representations of the San. Analysis herein is based on a blend of application of postcolonial theory and post-tourism critique, along with some concepts from semiotics. Most of these visual and linguistic materials have been produced by government and industry for tourist consumption, while others include my own photography and ostensibly impartial museum exhibits.
\end{abstract}

Keywords: San, Bushman, Basarwa, appropriation, eroticisation, the tourist gaze, visual imagery, postcolonial and post-tourism critique, neo-colonialism

\section{Introduction}

Through the analysis of tourism texts, both written and visual, via semiotic tools and the deconstruction of colonial motifs (or tropes) within a neo-colonial context, this article demonstrates the binary nature of tourism, with its inherent capacity for good and for ill. Tourism is usually situated within a capitalist paradigm and often seen as an opportunity to disseminate capitalism to the developing world, thus perpetuating a culture of dependency. As stated by Sherlock (2001, p. 280), "Both tourists and resident consumers are motivated by collective and self-identity, dreams and desires, as much as rational material needs."

Mowforth and Munt (2003) see tourism as a form of "hegemony in practice" (p. 48), whereby political, cultural and moral values eventually permeate the consciousness and values of subordinate groups, thus enculturating them in capitalist principles or towards the same human rights and/or environmental issues that concern the West. Further, Urry (2002) argues that new or alternative tourism practices are simply a postmodernist response, naturally amalgamating tourism with other practices, such as education.

In this context, the aim of this article is to analyse a range of visual representations of the San, who are First Peoples of the Kalahari, commonly known outside Africa as 'Bushmen' and in the dominant language of Botswana as Basarwa. This particular group is represented by government and its corporate affiliates as primordial for tourist consumption, yet systemically denied their language, ethnicity and ancestral land. Notably, the images analysed here are produced without the explicit authority of the San. Since ethics clearance would not have been forthcoming for anything other than anthropological work in this area and there is welldocumented hostility of the Government of Botswana towards research into ethnic minorities which officially do not exist, I use material that was already in the public domain, including tourist ephemera such as airline, safari lodge and tour texts, galleries, craft shops and museums. I supplement this with photographs taken by myself, expressly with the permission of those photographed, during the period 2010-2015.

The organisation of the article is as follows. In Section 2, I present the theoretical framework, which combines post-colonial theory (e.g. MacLeod 2007) and post-tourism critique (e.g. Sherlock 2001), along with ideas from Barthes $(1979,1987)$ and Paglia (1990). In Section 3 , I investigate two different manners in which photography can be used to promulgate 
perceptions of an ethnic group: either perpetuating disenfranchisement within a political assimilationist model that benefits from this marginalisation, or at least attempting at a more just form of representation. Section 4 applies semiotic analysis to the art-and-craft work that further fosters representation of the San as primordial and elemental, rather than members of the $21^{\text {st }}$ century with equal recourse to the body politic. I conclude with a summary in Section 5.

\section{Theoretical framework}

The two theoretical persuasions to be combined for the purpose of the analysis are postcolonial theory and post-tourism critique. As MacLeod (2007, p.9) asserts, postcolonialism "does not glibly mean 'after colonialism' as implied by the misleading axis of the hyphen in the term 'post-colonial'. Rather, it is a term which describes, evaluates and helps to configure a relationship: between reality and its representation." Accepting this reasoning, the term is consciously unhyphenated in this article.

Mishra and Hodge (2005) argue that it is important that when considering postcolonialism it is important to be aware that bourgeois anticolonial nationalism is merely another form of colonialism. In many African countries, certainly evident in post-1966 Botswana, "postindependence Africa emulated ... the colonial legacy ... a black African elite replacing the colonial elite" (Samatar 2006, p.19). Fanon (1968, as cited in Ashcroft, Griffiths and Tiffin, 1995, p.157) gives a cynical description of such elites, thereby providing an apt characterization of those of the Botswana establishment:

[A]s soon as independence is declared, far from embodying in concrete form the needs of the people in what touches bread, land and the restoration of the country to the sacred hands of the people, the leader will reveal his inner purpose: to become the general president of that company of profiteers impatient for their returns which constitutes the national bourgeoisie.

While colonial rule brought all Botswana together under one authority, "it also maintained and petrified the divisions amongst them" (Samatar, as cited in Mogalakwe 2003, p.92). Following independence, the colonial administrator's party of choice (the Botswana Democratic Party) became the ruling party and has been in perpetual power since 1966. Radipati (2006, p. 165) defines decolonisation in terms of the San in postcolonial Botswana in the same vein, noting that decolonisation simply affirmed "the self-determination of those dominant 'native' communities at the expense of Indigenous people". Thus, San self-determination on decolonisation was not a natural outcome since San communities were already dispossessed of their ancestral lands and "progressively weakened by the confluence of conquest, colonization and independence movements" (ibid).

As far as tourism is concerned, a central premise for this article is that although the principles and practice of tourism are becoming more enlightened in terms of at least acknowledging cultural integrity, there are still many examples of operators who exploit a "noble savage" ideal, keeping the culture static within a representation paradigm in order to sustain a lucrative tourist commodity. This has prompted Sherlock (2001) to define tourism as "one form of creative destruction" (p.287). The romanticised aesthetic of there being an ancient people still living as they have done for millennia, in harmony with the land, is limiting and potentially condescending. Cultural tourism theory does acknowledge this, in a critique known as post-tourism. This critical frame "transforms these processes by which the tourist gaze is produced and consumed" (Urry, 1990, as cited in Hutnyk, 1996, p.206) towards an awareness of the "links between the tourist experience and the everyday aestheticized consumption practices that pattern life" (Sherlock, 2001, p. 271).

Apart from these sources, I adopt concepts from semiotics, above all based in Roland Barthes' work on photography and mythology (Barthes, 1979, 1987) and that of Paglia (1990) on eroticisation. 


\section{Photography}

Photography, in particular in the way it is used in the present study, can be characterised in two quite different ways. The first is the manner that Urry (1990) identifies, whereby the technology has "become emblematic of the tourist ... of being seen and recorded and seeing others and recording them" (p. 138). This is clearly a form of appropriation and associated idealisation. This manner of using photography is typical for cultural tourists and their contact with the outside world, through the uploading of images and information to social media in "a new blurring of space" (Wang, Xiang, Fesenmaier, 2014, p.2). This is a phenomenon whereby tourists can exist in a touristic space simultaneously with their everyday lives at home, thus broadening the geographical reach of their (often erroneous) impressions.

In their research in Namibia's living museums, Hiri and Mokibelo (2012) note tourists taking photographs and "selfies" with San people. Thus, dichotomies that traditionally characterised the travel experience such as home/away, authentic/inauthentic, extraordinary/mundane are potentially undermined, by way of the internet's global connectivity (Wang et al., 2014). This may be seen as de-exoticising the experience to some extent, but the San are still held at an exotic remove through, sometimes unconscious, "othering". While the exoticisation underscoring the myth of authenticity is an industry imperative, the camera's capacity to blur space may eventually have a ubiquitously positive outcome, as with San artist Qaedhao Moses' and his students' self-representation outreach to tourists, discussed in Section 4.

The tourist experience is also reflected in photography produced in brochures and magazines by government and industry. Photographs and other visuals such as those in Figure 1 are patently attempting to create an impression of authenticity for tourists and can be analysed in the light of San representations as either "doomed race" or as "children".

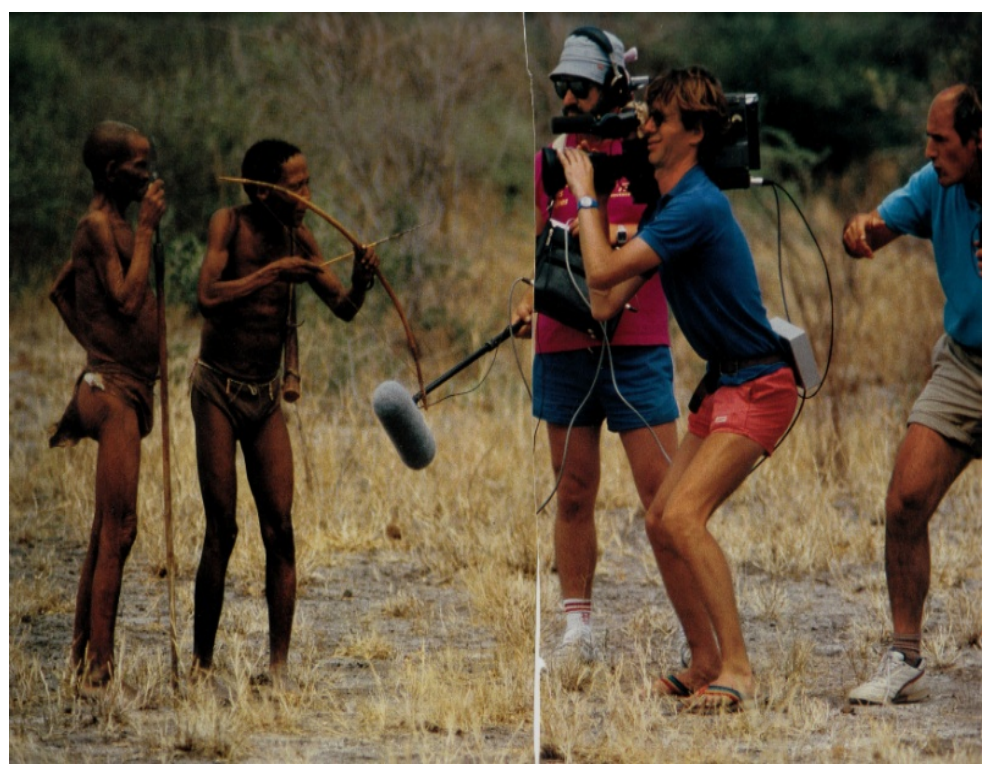

Figure 1. French television crew filming the San, Central Kalahari Game Reserve, Botswana. Photograph by Frans Lanting, National Geographic, 178, 6 (December 1990).

The second manner in which photography is used in the present study is in line with the point made by Moynah (2008) that: "[i]t is important not to take the camera as a metonym for the tourist [since] tourists exceed their gazes and in that excess lies the potential for disrupting domination ... rendering unstable the tourist's gaze ... [it provides] a means of challenging the Eurocentric epistemologies" (p.39). Photographs taken by myself (e.g. Figure 2) and 
anthropologists (e.g. Figure 3) showing San people in their daily activities may thus be seen as a resistance of sorts to the first type of photography. But let us start with exploring this first type in more detail.

The obvious set-up evident in Figure 1 reveals the contrived and decontextualised nature of much commercially produced representation of the San for tourist and general Western consumption. It epitomises the colonialist attitude of idealisation in its appeal to audience ingenuousness, suggesting as it does that the San are still hunter-gatherers with unfettered access to land and wildlife, and by extension, with no role or place in modern society. This calls up Barthes' (1979) contention that it is the nature of the photograph to show what "is dead and is going to die" (p.96), ultimately reducing the "subject to object" (p.13). The position of National Geographic, having included the camera and crew with the San "hunters" in their double-page spread is one of ironic exposure of the French crew's fabrication, at the same time as the device endorses the unequal power relationship between the viewer and the viewed. The magazine acknowledges the "commercial fantasy" (see below) depicted in this photograph, and was apparently aware of the disruption and subsequent decimation of culture that relocation from the Central Kalahari Game Reserve (CKGR) caused and continues to cause for the community. The caption accompanying this photograph reads:

"Look fierce and don't smile for the camera". Those were the instructions given by this
French television crew to Dzu Bushmen living in the Tsodilo Hills. Today few Bushmen, if
any, live as simple hunter-gatherers in the manner of their ancestors. Paid to shed their
Western clothes - and to pretend to stalk the crew's helicopter - they are being used to
perpetuate a commercial fantasy (National Geographic. 1990, pp. 50-51).

The insult inherent in this contrived "fierceness" is embedded in the irony of the San's actual powerlessness in the face of "Tswanatization", an inscribing of the assimilationist project of the Botswana government whereby ethnic minorities are not systemically recognised but rather required to conform to the dominant Tswana agenda and the marginalisation and poverty that result from such negation (Lekoa, 2007a). Even more so since the paying off of the San to perpetuate a lie is anathema to the cultural mores of the San whose ethic is traditionally open and honest, uncharacterised by deception (Hays, 2000). As Lekoa (2007b) asserts based on her empirical research, payment to the San for their participation in this charade is meagre and often in the form of clothes, tobacco and food parcels. Sylvain (2005) critically notes San exploitation by the tourism industry on the Namibian side of the border with Botswana: "[w]here Bushmen ethnotourism ventures ... are in the hands of non-San ... the very people who help to sustain the myth that the ... San remain pristine foragers, in need of nothing but game and wild fruits, are the first to believe that myth when payday comes" (p. 365).

The moving image implied by Figure 1 (as it would have eventually appeared in the French television production) is reminiscent of the curatorial introduction to a catalogue of a 1987 exhibition titled Cross-References: Sculpture into Photography where "[t]hese artists have little interest in photography as documentation of visual fact; rather, they prefer to arrange events to create their own realities ... By fabricating their own subject matter, these artists maintain an unusual degree of control over the resulting photographs" (as cited in Barrett, 1996, p.139). In this case, the San are being fashioned much as a sculpture is manipulated by its artist. The illusion that the people are still living on the land in their natural state is cleverly contrived when, in reality:

... tourism schemes have replicated the colonial system of separating people and the environment. As a result, local people may be excluded from national parks, and can be fined or arrested for trespassing and hunting in areas they have historically used. These exclusive areas are then developed with relatively open access for international tourists (Van der Duim et al. 2006, as cited in Smith \& Robinson, 2006, p.101). 
The phenomenon of aestheticising photographs, in spite of, or even enhanced by, their depictions of poverty and despair, effectively dismisses the plight of the people photographed and hinders any attempts to transcend their position in society. Barrett (1996) cites Walter Benjamin who in 1934 bemoaned the fact that photography "has succeeded in turning abject poverty itself, in handling it in a modish, technically perfect way, into an object of enjoyment" (p.93). Barrett also cites Susan Sontag (1977) who holds certain photographers accountable for distancing us using:

\begin{abstract}
... superb photographs of Agony, conforming to Surrealist standards of beauty ... their lovely compositions and elegant perspective easily outlast the relevance of the subject matter ... The aestheticizing tendency of photography is such that the medium which conveys distress ends by neutralizing it. Cameras miniaturize experience, transform history into spectacle. As much as they create sympathy, photographs cut sympathy, distance the emotions (ibid).
\end{abstract}

One may note the capital letter in "Agony", as though it is an aesthetic genre unto itself. Barthes (1979) has discussed insightfully the capacity of a photograph to offer up singular nuances of feeling, and the insidious classification at work with photography, where the subject becomes object as cited above. He discusses his own photograph as "death in person" since, "what society makes of my photograph, what it reads there, I do not know ... they turn me, ferociously, into an object, they put me at their mercy, at their disposal, classified into a file, ready for the subtlest deceptions" (ibid, p.14). This analysis can be with even greater strength applied to the Botswana San context. Cook and Sarkin (2009) note that it is ironic that Indigenous groups have occasionally had to reformulate their ethnic identities in order to access resources. They cite the fact of the San being expected to perform as authentic "bushmen" if they are not to be labelled opportunistic in their claims to land, royalties and self-determination, while the English can live as modern people and simultaneously lay claim to a heritage of idealised landscapes, supremacy at sea, colonial glory and royalty.

Moving images also impact upon perceptions and are often produced by tourists for other tourists. The video clip How to find water in the Kalahari Desert - Bushman walk, Ghanzi (Africafreak, May 6, 2011) depict the San in traditional clothing in the desert, showcasing ancient skills. The tourists appearing are mostly standing over the family group, the patriarch of which shaves at a tuber, producing handfuls that are then kneaded and squeezed, producing water for drinking and washing. While admiring idealisation of the San for their skills is evident and there is, refreshingly, no voice-over offering Western interpretation of the tableau, there is also no critique. The scene is simply taken at face value. The title of this and related "how to" clips on the Internet imply that these San practices are accepted by tourists as sui generis and definitive, with no corporate deception operating. For example, tourist largesse is suggested with the cigarette being passed around the family. Although the occasional laughter of the San indicates that they are not unwilling participants, witnessing and close-up filming of an intimate family scene with infants at mothers' partially exposed breasts and people washing themeselves could be read as voyeuristic.

The line between voyeurism and awareness-raising is sometimes difficult to locate, however. For example, the effect this videoclip could have on the more ingenuous viewer could become a kind of reversal, of the kind identified by Gillespie (2006) who, apparently in response to Urry's "tourist gaze", writes of the "reverse gaze ... the gaze of the photographee on the photographer as perceived by the photographer" (p.34).

The photograph in Figure 2 is an example of the quandaries faced by those wishing to expose injustice, but who may unwittingly violate human spaces and sensitivities in the process. It shows a San woman making ostrich-egg beads for necklaces such as those displayed in Figure 6 in the next section. She and a few other women are seated on the ground outside Gantsi Craft shop in Ghanzi, undertaking an everyday enterprise. On the one hand, the woman's direct gaze is reminiscent the "strategic reversal of the process of domination [which turns] the gaze 
of the discriminated back upon the eye of power" (Bhabha 1994, pp.107-108). While the woman is emphatically not discriminated against by me as photographer, I know her to be a member of a group which continues to experience debasement in the region. Although I had no desire to exploit it, I acknowledge my position of economic and social advantage over her. As a result, the dynamic of my brief encounter with this woman and the taking of the photograph certainly disturbed me.

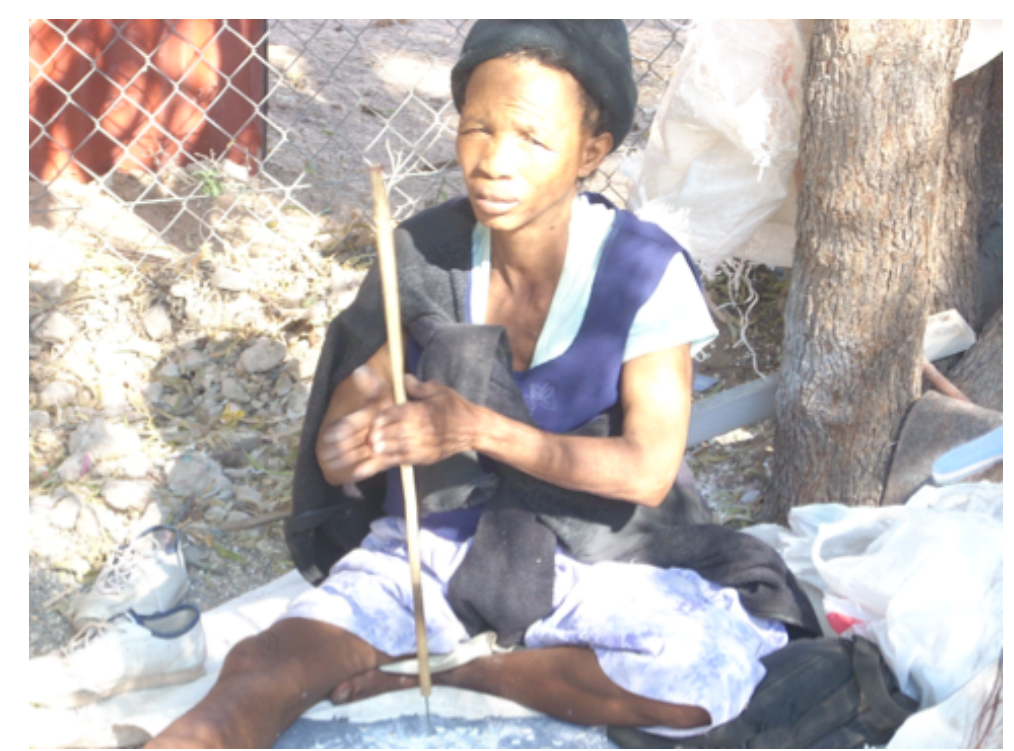

Figure 2. San woman making beads from ostrich egg-shells, Ghanzi. (Taken by the author with permission from the woman)

By way of comparison to the contrivance evident in Figure 1, certain salient factors stand out. Certainly I made no requests of the woman to "perform" in a certain way for the photograph. I am physically with her; there is eye contact. The woman's seated position appears open towards me, which can be read as a human connection, perhaps even trust; however, the brevity of the timeframe could simply mean she was not able to rearrange herself. The light is a capture in that the reality of the woman's yellowish skin - an oft-noted feature of the San - is accentuated. The manner in which the woman uses the stick to fashion the eggshell into beads is redolent of the rubbing of sticks for the production of fire, another ancient practice. My unconscious elevated position while taking this photograph is, however, consistent with the higher value of the observer than the one being gazed upon, as pointed out by Spurr (1998) in his analysis of "disproportionate economy of sight" (p.17).

My critical reading of the woman's facial expression and body language is in itself a product of "majority world" privilege and there is an inherent arrogance in imagining I know what the woman might be thinking. The intent in this photograph was to capture the look of (what I read as) melancholy on the woman's face, her look directed at me unambiguously, reflecting her difficult life and presumably believing me to be yet another tourist with the capacity to afford the luxuries she labours over, but from which she receives little benefit. Bhabha (1988, p. 23) calls this phenomenon an "ambivalence in the act of interpretation", asserting that interpretation is never a simple I-You exchange and that the "discursive conditions of enunciation ... ensure that the meaning and symbols of culture have no primordial unity or fixity; that even the same signs can be appropriated, translated, rehistoricized and read anew". My gaze subjectively identified with the woman (see Burgin, 1982) but I concede I was perhaps identifying with what I know of the experiences of her people rather than with the woman herself. Although I read (accurately or 
not) the woman's "reverse gaze" as being acutely aware of the disparity between us, this may be my over-interpretation.

Evidence for this is that, as Lekoa (2007b, p. ix) points out, the San are largely ignorant of the extent of the difference, partly because they do not see their handiwork overseas: "[t]he sad part is that here they don't know how much tourism is exploiting them. I saw a San painting in an exhibition in Norway, selling for thousands of Euros and I know the artist himself received a pittance for it". The rhetoric of the Botswana Tourism Board, however, suggests the San reap the benefits of their labour: "[t]oday the descendants of the Kalahari's original peoples usually work at the district's cattle and livestock farms, but are increasingly becoming involved in the tourism industry. Some are engaged in community-based tourism projects, others prefer to produce their unique arts and crafts for sale to tourists" $(2009$, p. 70$)$. Even an academic onlooker appears to stand as an apologist without critical analysis, endorsing the rhetoric: "Gantsi Craft currently serves several remote settlements within Ghanzi and Kgalagadi districts, buying crafts directly from producers and the majority are women" (Bolaane, 2014, p. 55). Yet the sources of Bolaane's information appear to be the Gantsi Craft flyer for 2008 and the Molapo Kalahari Lodge flyer of the same year. It is not mentioned that the community-based projects largely benefit corporate tourist outlets and the San have little choice but to comply, given their (linguistic and other social) incapacity to deal directly with the public.

Weinberg (1997) who took the photograph shown in Figure 3, chronicles his observations of D'Kar, its origins, rhetoric and realities: "Bushmen are regularly evicted from farms and dumped at D'Kar. I meet Qama Qaxee and his wife, living in a tiny shack. He asks for money and points to his stomach" (pp. 24-25). While Weinberg is publicly sceptical of the Kuru Development Trust's motives for intervention in the San's lives, his photographs are sold as postcards at Gantsi Craft with the contact details of the Kuru Development Trust on the back. Weinberg labels his photograph of the mother and child, giving the name of the mother, thus asserting her individual personhood. It is, at least, refreshing that the imagery does not overtly suggest primordialism or employ idealisation by way of harmonious family scenes, hunting or gathering. The photographic set-up is not a hyper-real representation, rather one that is unconstructed, reflecting, in the meagre surroundings of the camp, the general reality of San conditions in the Ghantzi area (see Lekoa, 2007b). The black and white rendering of the scenes, however, may be read as an aestheticised construction, suggestive of the ancient, the elemental (no technology evident, organic textiles and utensils) with the obvious poverty perhaps serving as an aesthetic to certain interpretations. 


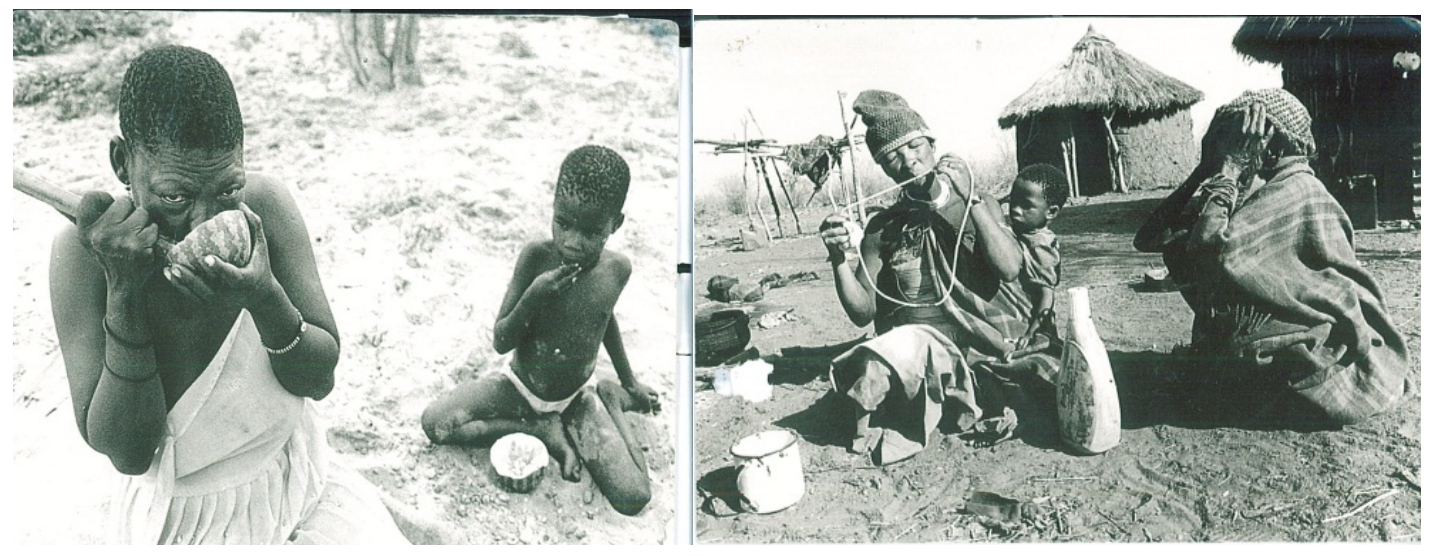

Figure 3. Dibe Sesna and her child eating tsama melons (left) and making ostrich necklaces in a settlement outside the Central Kalahari Game Reserve, Botswana, (right) (Photographs by Paul Weinberg)

Some aestheticisation of poverty could certainly be at play in the two images of Figure 3 . Spurr (1997) contends that people of the developing world are represented as being unprotected by more advanced civilisation; their suffering depicted as "raw and elemental", those aspects that are successfully suppressed and reined in in the West. Further, such representation is a particular kind of construal, since "the aesthetic stance itself is taken from within a position of power and privilege; the power to perceive poverty as aesthetic value is a privilege not granted to the poor" (p.47).

Just as photographic images can manipulate the credulous tourist, commodified artefacts also play a role of contrivance (in feigning authenticity) and fraudulence in allowing tourists to believe that the proceeds of the sale always benefit the makers, as discussed in the following section.

\section{Arts and crafts}

Prasad and Prasad (2002) observe that: "[t]ravel agencies, hotels, tour operators, cruise lines and the like design and market a set of experiences that supposedly provide opportunities for close and playful encounters with exotic native cultures" (as cited in Prasad, 2003, p.161). This set of experiences in the Botswana San context takes the form of art and artefacts to buy, ritual dance to observe and survival tours to join. All these products satisfy aestheticisation and idealisation of the San as commodities, resulting in appropriation with little critique applied to the process. Similarly, Liesbeth Groenewald (2008) notes within a South African San context, applicable also to the Botswana setting, that despite a postmodern capacity to apply critical literacy, "tourists often gaze upon San artefacts and performance without understanding or engagement, as the overabundance in number, variety and presence of images ... interferes with our ability to look and reflect on individual images" (p.42).

The Kuru Art Project, D'Kar, can be considered a case in point of idealisation, selling artefacts designed for the unwitting tourist. The rhetoric of the project omits any mention of dispossession of the Naro San of their traditional hunting ground, which originally occurred at the hands of Afrikaans-speaking white farmers (encouraged by the British government) and more recently by government on behalf of Debswana and Wilderness Safaris and other lodges in the Central Calahari Game Reserve (hence, CKGR). Brown (1999) asserts that: "[t]he approach of the art centre has not been to present art lessons at all but rather to provide facilities, materials and encouragement to the group of ten San artists who are invited to play and experiment and thus teach themselves a personal way of handling the materials" (p.30) [my italics]. This calls up the problematic concept of authenticity once again. Brown (1999) attributes international 
recognition of San art to the centre, as does Qaedhao Moses, whose award-winning artwork has sold in the USA and Australia and who now has a workshop within an artists' cooperative in Botswana's capital. Moses was given an apprenticeship by Kuru Family of Organisatons (hence, $\mathrm{KFO}$ ) but this indebtedness to the centre came at a price which, apart from the substantial commission the organisation extracts from the selling price, is the obligation to create art that only represents what it is assumed tourists expect depicted in San art, in keeping with the preconceptions they have about the San. Examples of his art are shown in Figure 4, along with other San artists.
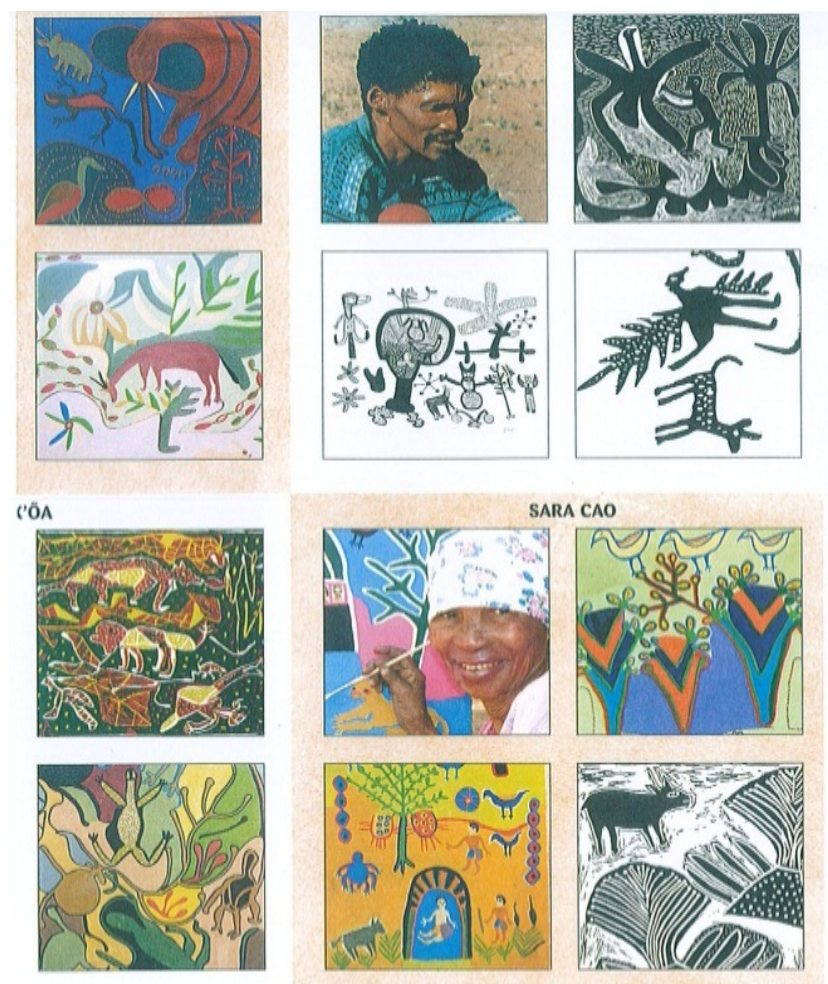

Figure 4. Works of Qaedhao Moses and other San artists, reproduced from Kuru Art project booklet.

As is evident from one of the four similar pages of artwork and artists of the Kuru Art Project booklet (Figure 4) not one collection depicts modern realities of the San. Prasad (2003) identifies the aestheticisation at the core of this practice:

\begin{abstract}
Native arts ... are largely undifferentiated, reproducing an older colonial discourse in which Western art is appreciated for its variation and nuances, while native art is valued for its capacity to symbolize certain broad cultural patterns ... [with] little interest in vibrant contemporary native cultures given their romantic preoccupations with preserving supposedly dead ones. ... the native is of interest only as an exotic other who typifies a "pristine" non-Western state uncontaminated by the effects of change and modernity (p.164).
\end{abstract}

Gantsi Craft, in operation for almost thirty years, makes much of its interactions with fourteen resettlement communities to produce craft, understanding the market, sourcing natural products obtained under government license and refusing material from poachers. Steiner's (1999: 101) observations on the "creature comforts of the canonical", are patently manifest in exhibitions staged by Gantsi Craft, collaborating with the Kuru Art Project and some other NGOs to produce work that has the stamp of "authenticity". A similar attitude is expressed by an article from Peolwane, Air Botswana's inflight magazine (2007, p. 21): 
San craftmaking has recently caught international attention and has entered the scene of haute couture! During the past few years, Gantsi Craft has taken part in a regional initiative with the internationally acclaimed French designer Michael Kraa, who inspired the craft producers to turn their traditional San ostrich egg jewellery into highly fashionable and trendy jewellery for their European market.

San artist Qaedhao Moses demonstrates the way in which he currently practises resistance against the official rhetoric of San "authenticity", by way of his representation of modern San realities. In Figure 5 he is photographed at his workshop in Gaborone with some of the traditional artwork he paints, typical of the work produced by the San of the D'Kar region. Moses claims that although tourists are still interested in buying images they believe to be based on San rock art, they are becoming educated towards an understanding of the San as a people with the potential to have a place and a voice in modern Botswana but whose efforts at selfdetermination have been systematically thwarted over many generations. In the interactions between Moses and myself, the "tourist gaze" is not occurring with any manner of imbalance since he readily agreed to be photographed with his art.

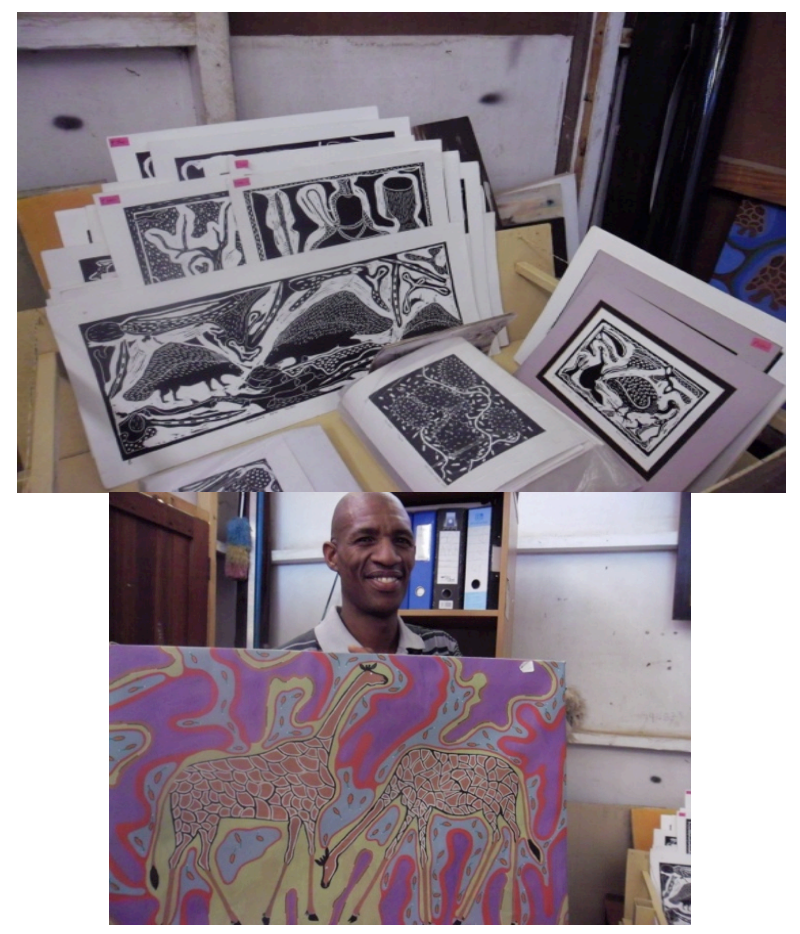

Figure 5. Qaedhao Moses, San artist, formerly of D'Kar. (Photographs taken by the author with permission from Qaedhao Moses)

Appropriation as a form of reinterpretation applies to stylistic elements of culture where outsiders have preconceived notions about an ethnic group, which they then reproduce. Or else, as in the case of the art that Moses was required to produce before deciding to strike out on his own, to have it reproduced by members of the indigenous community, in a way that aligns with their perception of "authenticity". Such reproductions of the rock art are in fact stylistic fabrications, in that they "separate the content of a painting from the form which expresses it [since] re-creations of the paintings ... bear little resemblance to the originals" (Deacon and Dowson, 1996, p. 237). Portrayal of such "traditional" versions of themselves for tourists shows a "well developed sense of self-objectification and self-commodification" (Salazar, 2009, p. 60). This phenomenon shows how some ethnographic and archaeological conclusions can foster representations that become commodities, thereby perpetuating a myth of authenticity and essentialism that can keep minorities disenfranchised. Guenther (2006) concurs, noting a 
similarity in style in the paintings produced through KFO in D'Kar to the rock art, "in part because some of the artists have taken Kuru-sponsored trips to far-away rock-art sites". However, he calls these "eerie echoes" merely a "romantic ringing in Western ears" (p.176). Guenther cynically attributes the common tourist desire for the "tribal, feral, childlike, primal, ancient and archaic, dark, at one with nature and kindred to animals" (p. 176) in the art they buy to a correlation in the Western mind between authenticity and primitivism. He posits this perpetuated and constructed orthodoxy in terms of the authenticity myth in that the "externally derived" values and techniques of Western NGOs drive the artistic process and the subjectmatter with no relation to San realities in modern times. This phenomenon also inevitably results in cultural essentialism. According to Skotnes (1996), such essentialist artistic recreations are disrespectful since they do not account for the intra- and inter-regional stylistic, formal and iconographic differences and contradictions which stand as tangible markers of cultural diversity:

Deprived of their aesthetic significance, they are viewed as ethnographic specimens or productions of the "primitive" mind however full of religious feeling it may be acknowledged to be, mere illustrations of San belief or illustrations of theories of San belief ....it is this reduction of the paintings ...that has enabled the researcher to find such widespread similarities in the paintings and posit a pan-San cognitive system (p. 238).

Figure 6 shows San work on sale for tourists in Ghanzi, Botswana. As evident from the credit card icons on the windows, the level of prices charged for the handiwork is high, even by Western standards. The idealised suggestion inherent in the collection is that the ostrich shell necklaces, leather pouches, etc. are authentic items, still used by the San today. In fact they are used and worn only for tourist gratification, as graphically shown in the over-aestheticised (and eroticised) commercial image in Figure 7.

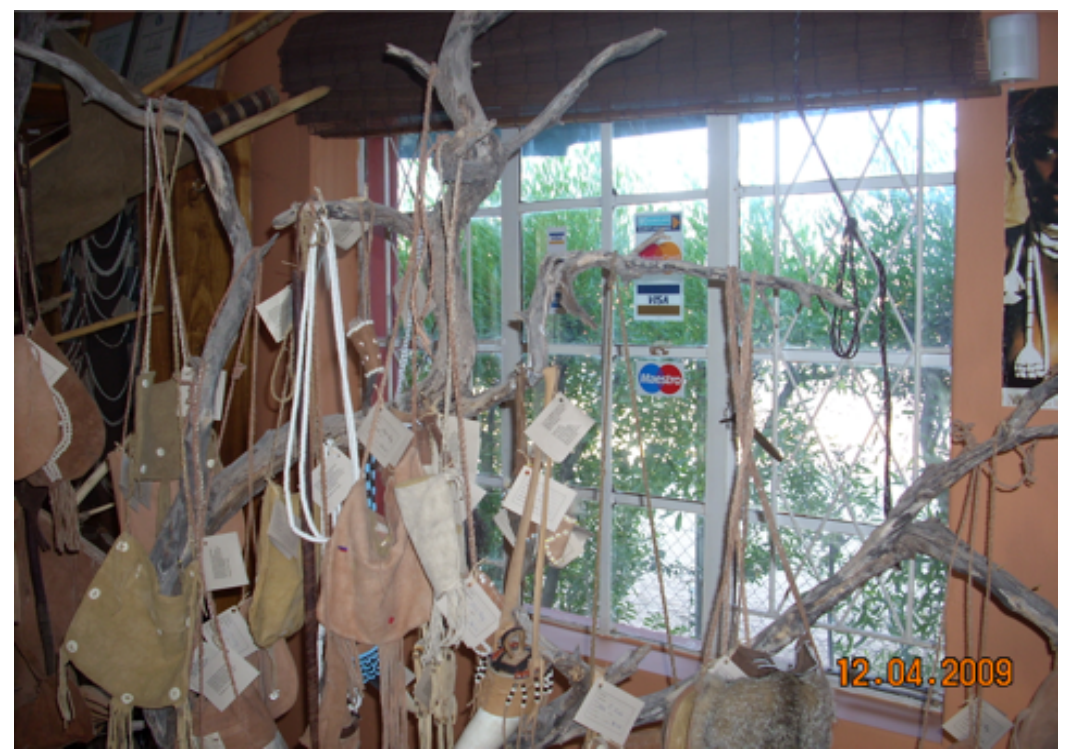

Figure 6. Interior of Gantsi Craft, Ghanzi, Botswana (Photograph taken by the author, with permission from Gantsi Craft management) 
R. Thomas

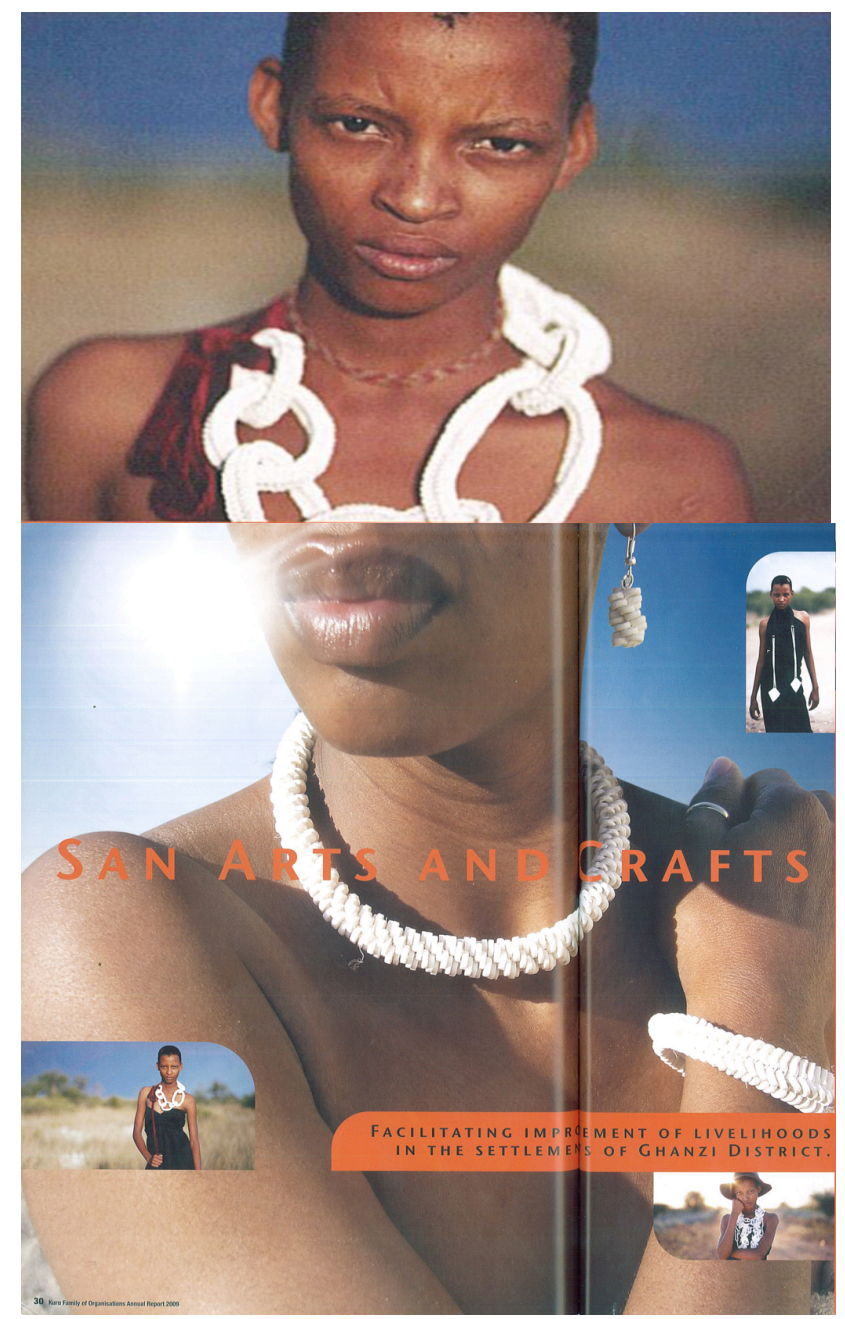

Figure 7. San Arts and Crafts (Photographs from Kuru Family of Organisations Annual Report, 2010)

I eschew any suggestion that the women shown in Figure 7 have no agency in their roles as models. There is undoubtedly, though, eroticisation at work in the images showcasing San craft in a KFO glossy annual report advertising ostrich-shell jewellery adorning San women. While the same could be claimed for all such imagery in this genre, the irony of the symbolism in this case is particularly pertinent. Glowing affirmation of the role of KFO in the sourcing, design and marketing of such a quality product is also evident, as well as loving affirmation in a memorial spread about the recently deceased Bram Le Roux who founded KFO. The report is ostensibly for the information of NGOs affiliated under the KFO banner but is available gratis to tourists in KFO-supported outlets, such as Gantsi Craft and the D'Kar Museum and Art Gallery, thereby serving as a material promotion of the organisation(s)' benevolence and as an advertising medium.

However, one cannot deny that the tourist industry is heavily marketed with sexualisation, as asserted by Aitchison (2001): "[f]eminized, sexualized and radicalized imagery can be seen to inform a symbiotic relationship between colonialism and sexism that constantly reinvents itself within the globalized tourist industry" (p. 140). She also acknowledges the metaphor of the feminised (and thus relatively powerless) site as a "social-cultural nexus of gender-power relations in leisure and tourism ... in which the gendered Other is constructed as subaltern in and through tourism" (pp. 134-135). This is a form of semiotics that seduces visitors with the old "sex sells" adage which, in the words of Butler (1990, p. 136), is part of the "epistemological, 
ontological and logical structures of a masculinist signifying economy". Lack of resistance from the locals is highlighted by Aitchison who, placing tourism firmly within a neo-colonialist paradigm, comments that the landscapes offered up for tourists (including corporeal ones) are frequently shown as "hidden treasures or as canvases upon which the explorer or the tourist can make his (sic) mark without any local resistance" (ibid, p. 138).

The rhetoric directed to tourists as that in Figure 7 celebrates the international market the product has garnered and tacitly suggests that the purchase of this product will benefit the San community: "[f]acilitating improvement of livelihoods in the settlements of Ghanzi district" (p. 30). To those incensed by government treatment of the San, these words are evidence of KFO's acceptance of the fact that the settlements allowed to continue to exist! This lack of any protest about the communities created to accommodate evictees, sits alongside the eroticisation of the models as at least two glaring examples of offensive neo-colonialist hubris, couched in rhetoric of compassion and altruism.

The models' poses and facial expressions, as well as the photography, are Western conventions of the medium recontextualised in the desert setting. In the main photograph, the woman's face is only partially shown, shielding identity to enhance a sense of mystery, with the universally unsmiling and moistened pout of fashion models exuding sexual allure. Spurr (1998, pp.178-179) quotes the German poet H.F. Freiligrath's eroticised vision of Africa and its women, penned in 1874:

\footnotetext{
Oh, zone so hot and glowing,

Queen of the earth art thou;

Sand is thy mantle flowing,

The sun dost crown thy brow.

Of gold, thou queenly woman,

Are all thy clasps and rims,

That fasten with fiery splendour

The garment to thy burning limbs.
}

A century and a half later this aesthetic is still promulgated by way of polysemiotic messages such as that in Figure 7. But there is an insidious edge to the photographic images that tourists would almost surely miss. While it was undoubtedly unintended to be so, the necklace fashioned into a chain with large links worn by one model, is, apart from being a suggestion of sexual bondage, allusive to slavery. Since the San have been enslaved literally and metaphorically in chains for centuries and given the KFO's espoused mission, it seems in dubious taste to have one of the models so attired. Sensitivity to this historical and current fact in the setting up of this photograph was evidently overlooked.

The youth of the women is evident in all photographs in this spread: the girls appear pubescent, innocent, virginal. As Paglia observes, "[s]moothness is always social in meaning: it is nature subdued by the civil" (1990, p. 533). The fact that the images are designed and produced to solicit specifically Western custom categorises them in the vein of allegorical eighteenth- and nineteenth-century imperial text such as that of T.E. Lawrence. Personifications of Henry Morton Stanley's (1890) description of Africa as "still a virgin, locked in innocent repose" (p. 231). The desert features indistinctly in the background of all images; muted sunset lighting enhancing the sense of insubstantialisation and eroticisation simultaneously with the suggestion of untouched territory. Paglia's (1990) interpretation of Leonardo's Mona Lisa comes to mind with these models in that persona function as an:

... ambassador from primeval times, when earth was a desert inhospitable to man. She presides over a landscape of raw rock and water ... But the background is deceptive and incoherent. The mismatched horizon lines ... are subliminally disorienting. They are the unbalanced scales of an archetypal world without law or justice (p. 154). 
The reading of the background as untamed, suggests a perception of necessity to dominate such a context; to bring it into sharp relief, thereby to define it. In the vein of terra nullius, Paglia (1990) suggests that Mona Lisa's assumption of power over the landscape is, in fact, illusory; that the landscape is but a formless imaginary until defined and appropriated by an external (read: colonial/neo-colonial and male) agent. Paglia (1990: 3) inscribes this phenomenon as a manifestation of the daemonic, where:

[s]ex is the point of contact between man and nature, where morality and good intentions fall to primitive urges ... This intersection is the uncanny crossroads of Hecate, where all things return in the night. Eroticism is a realm stalked by ghosts.

Millum (1975) reads insubstantialisation in the "soft introverted" gaze where the model is "pouting, rarely smiling" as an "inward-looking trance-like reverie, removed from earthly things" (p. 97). But this photographic spread goes further: the androgynous aesthetic established for the women depicted (breasts covered by arms, masculine hat, etc) also situates the assortment within the Apollonian "correction of life" whereby "the early and high classic beautiful boy perfectly harmonizes masculine and feminine ... the beautiful boy slides towards the feminine, a symptom of decadence" (ibid., p. 123) as well as being "exclusive, a product of aristocratic taste" (p. 117). This androgyny could also be read as a challenge to the voyeuristic objectification of women (to Laura Mulvey's 1975 "power asymmetry" of the male gaze) that pervasively characterises fashion spreads.

Again, this interpretation of the aesthetic renders it ironic considering the San's conditions in the settlements. Conveniently, in terms of government and corporate agendas in the CKGR, the photographic set-up has the beautiful boy "[fleeing] the superfluity of matter, the womb of female nature" (p. 117) as though the area could not have any appeal for the San in any case; their aspirations are materially and culturally beyond that place. Subliminal appropriation is taking place by way of the suggestion to tourists that the CKGR belongs to a hazy past for the San who now subscribe to Western aspirations and values. This would appear to be a "bridging" sentiment, aimed at those tourists unconvinced by the primordial representations of the tourist industry, needing some reassurance that the San are content within an assimilated paradigm.

Paglia (1990) contends that the merging of humanity and wilderness into a continuum is "a classically Dionysian view of man's immersion in organic nature" (ibid., p. 236). But in these photographs, there is a foregrounding appropriated into embellishments in which the models are attired momentarily before returning them to such demographics that cannot afford such luxuries. Elevating of the sharp-focus human form against the "fuzzy, misty" backdrop Paglia identifies as "the western eye victorious" (p. 104) and sees it as quintessentially Apollonian, in a particular sense:

Apollo freezes the living into objects of art or contemplation. Apollonian objectification is fascist but sublime, enlarging human power against the tyranny of nature ... [in Greek society] what was far away, invisible, was ipso facto 'not there' (p.106).

The image can also be interpreted as a metaphor for the San in relation to the Kalahari, with the desert now unavailable to them, far away in terms of free access. The metaphor is embellished by the models wearing ostrich shells, as residual markers of nature.

A very different representation of San arts-and-crafts is used by the company showcasing their wares in Figure 8, San Arts and Crafts, the only Propriety Limited company within the Kuru Family of Organisations. It has consulted experts in the fields of design, marketing and branding and now has outlets in many countries. While the company boasts Fair Trade accreditation, the images are arguably imbued with notion of a Eurocentric "normative gaze" (West 1999, p. 80) by which other peoples are socially constructed. 


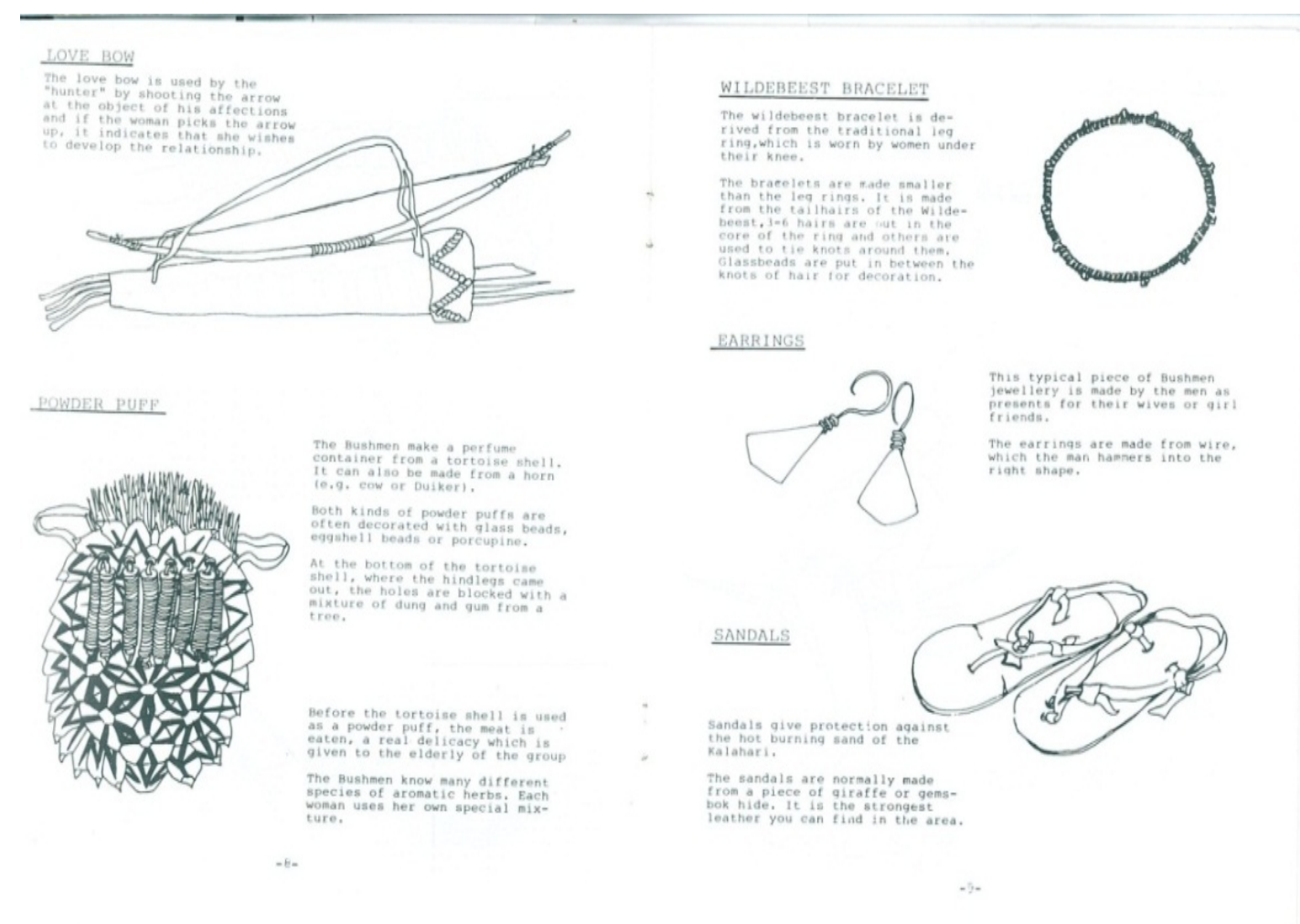

Figure 8. 'Bushmen Crafts', Gantsi Craft, Ghanzi District Botswana

The booklet from which Figure 8 is reproduced depicts the idealisation and aestheticisation (including infantilisation) at work in the line drawings of San craft work for sale. The booklet itself is plain-cover, unsophisticated, decidedly non-glossy, using font from a typewriter rather than a word processor. This, along with the present tense of the text, fosters the mythology of the San as an historical race: a people that does not need or use modern conveniences or materials, that lives a hunter-gather lifestyle as an aestheticised relic, occupying no position in modern Botswana. As Groenewald (2008) asserts with regard to the promotion of San artefacts, "[a]dvertising sells the past to the future via a sophisticated technology system, or a dream world where anything is possible. Advertising imagery therefore idealises the Bushman by portraying a specific 'image' of a primitive hunter and gatherer" (pp. 28-29). The booklet was produced for tourist consumption by Gantsi Craft, whose outlet sells very expensive versions of the items primitively sketched in Figure 8. Enhancing the concept of San primordialism in the tourist imaginary is thus a conscious construct manifest in the naïve style production of this booklet.

Appropriation of culture and artefacts for tourism is a practice explored in some detail by Duffy (2002). The definition of ecotourism extends to encompass culture, Duffy asserts: "it is meant to be socially and culturally aware [ensuring] genuine participation for local people" (p. 98). However, Duffy is well aware that her tourism ideal is an exception, while it is more common that "local people and their ways are customized, packaged and sold for consumption ... [as] when traditional rituals and festivals are re-enacted for the ecotourists' benefit" p. 102).

Figure 9 shows San art on display and for sale to tourists as a classification in itself. The gallery was established by the Le Roux family and now produces art which is exhibited and sold at high prices in Europe and North America (although this is mentioned only with reference to the fact of exhibitions, not to sales) as well as being sold to tourists on site. The art the San are encouraged to produce is based on the rock art of the Tsodilo Hills and certain other sites across southern Africa. It is meticulously catalogued and limited-edition prints of each original are made. The classification of the artistic subject matter further endorses the suggestion for tourists 
that the San are of the past, with no real position in, or contribution to make to modern Botswana. Appropriation of the artwork is also evident, as Coex'ae Qgam (2011) of D'Kar asserts:

We do these paintings and everyone says we are rich. They say we are getting a lot of money. Now I can't see that money so how can I believe that it is enough? If it was so much money, why would it be finished even before I have paid everything I need to and have given the children something? (p. 201).

This is confirmed by Hitchcock and Brandenburgh (1990) who assert that jobs given to Basarwa are often menial, consisting generally of catering positions. None of the safari companies is owned or operated by Basarwa. Management positions in the rapidly expanding tourism companies are usually reserved for non-Basarwa, many of whom are Western trained or have extensive experience. According to some Basarwa, tourism is out of their hands; it is controlled, they say, by private businesses or by the government, and they have little or no access to well-paying jobs" (personal communication, Eureka Mokibelo, May, 2024).

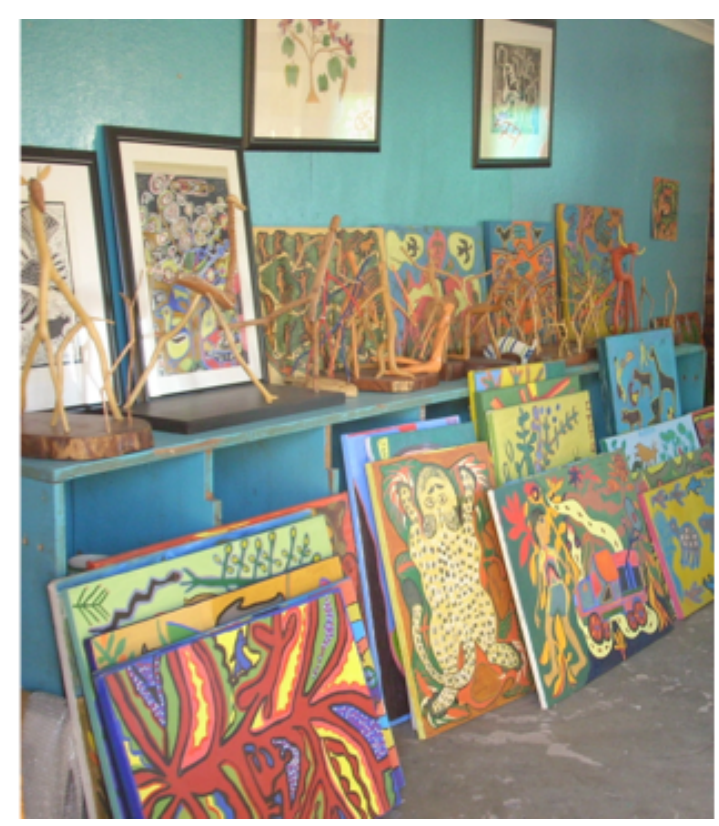

Figure 9. San art on sale in D'Kar, Botswana (Photograph taken by the author, with permission of D'Kar Museum and Art Gallery management)

Some years ago, the work of Coex'ae Qgam (Dada), shown in Figure 10, depicting a jackal in the bush adorned British Airways aeroplanes and company paraphernalia, symbolically aligning Botswana within the old colonial dynamic including the appropriation of Indigenous artefacts that has always characterised colonialism. Moses also notes a lack of transparency from Kuru Art Project as regards the cost of art materials, used as a justification for the meagre payment of artists. The exploitation involved in the appropriation of specifically San art in this instance is evidence of a neo-colonialist phenomenon in the fact that 'Tswana (or dominant culture) art could not have been so cheaply acquired by a corporation without contract or royalties. As Sheridan Griswold of the Botswana daily Mmegi (personal communication, October 28, 2014) recalls:

When British Airways ripped off [Dada] she was given a one-off payment when it should have been a combination of payment plus royalties, a proportion paid on all use over time (her art work not only went on a plane, but on tickets, luggage tags, even buses at Heathrow 
Airport) ... I had some interesting exchanges with British Airways at the time over their exploitative way of rewarding her. They refused to budge.

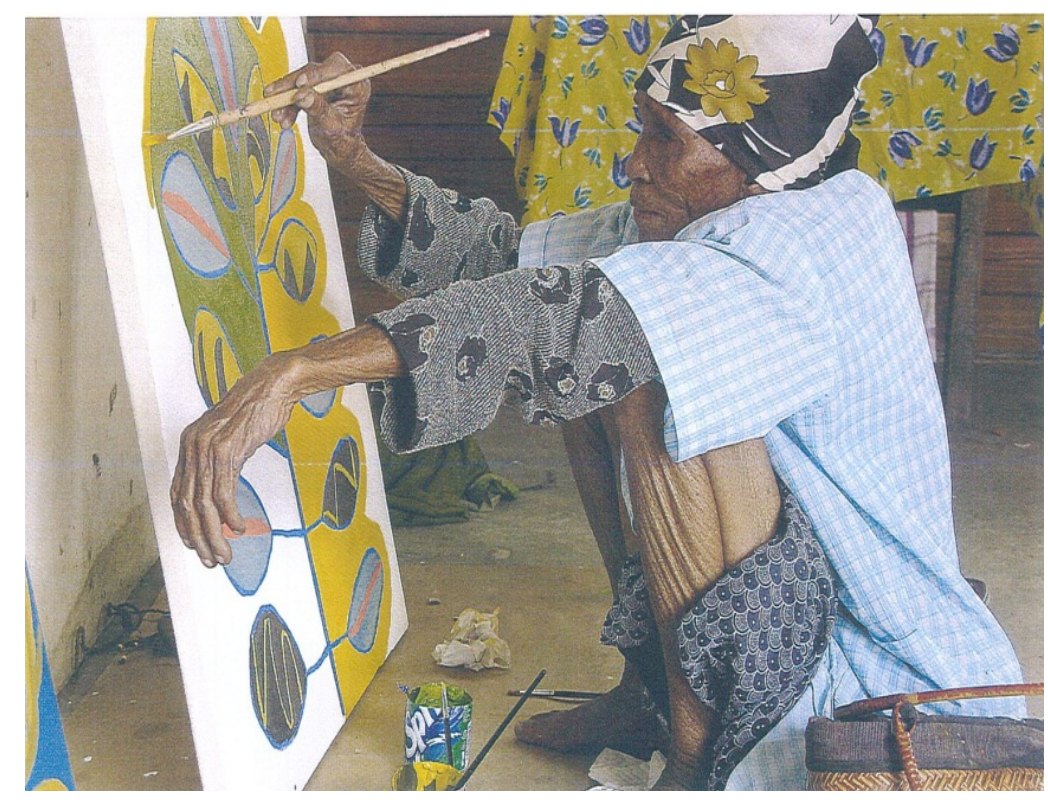

Figure 10. 'Dada', Coex'ae Qgam, (dec.) at work in D'Kar. (reproduced from Gollifer and Egner, 2011 with the permission of Ann Gollifer)

A book showcasing Dada's work was published in 2011. It can be read also as an example of resistance. It should be noted though, that while the book is a loving tribute to Dada's artistic talent and her place as San elder (she died in 2008) it was produced with the assistance of the Kuru Art Project; contracts were drawn up by Botswana's Human Rights Centre, Ditshwanelo, and authored by two of the artist's non-San friends. Although this collaboration is laudable, and Dada's book would not have been published without such assistance at that time, this also shows the lack of San self-promotion, and the need for San issues to be articulated by the San themselves.

In stark contrast to this, we can consider the statues shown in Figure 11. They are life size, showing the diminutive stature of the San. The photograph was taken with a view to capturing the lush surroundings which are anathema both to the vegetation of Botswana and the modern lifestyle of the San. The photograph was also deliberately taken from a standing position, simulating the typical (physically larger) Western gaze as looking down upon the San, as both a literal and a figurative positioning. The figures appear incongruously in the grounds of a luxury safari lodge in Botswana, an aestheticised image of two hunters in traditional garb involved actively in the pursuit of an animal. 


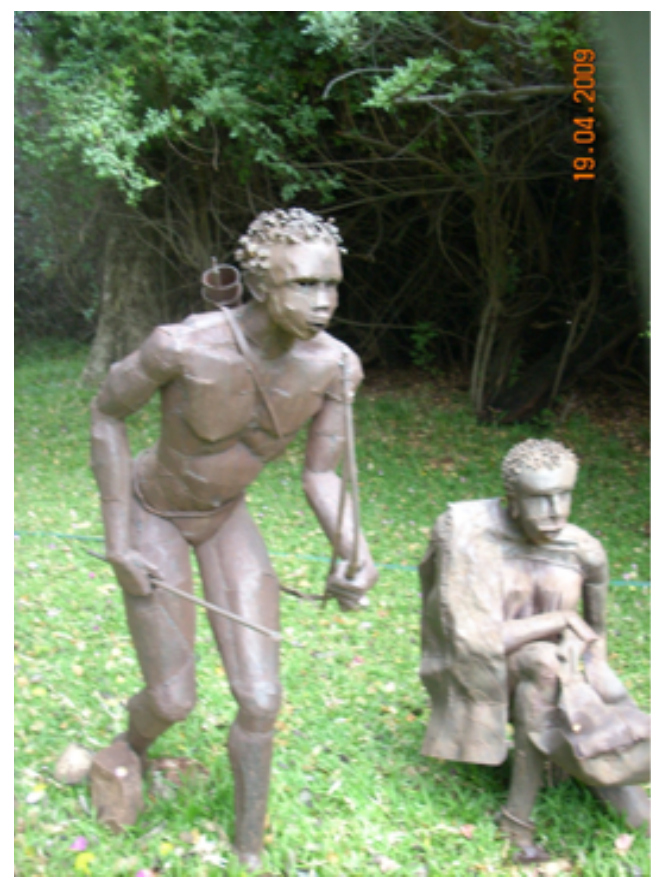

Figure 11. Statues of San hunters, Safari Lodge, Kasane, Botswana. (Photograph taken by the author with permission from lodge manager)

These statues are an example of idealisation in the sense that it is exactly this image of the San that tourists come to Botswana to see (after the animals) and, as such, the artifice is a tourist text, suggesting to tourists staying at the lodge that the San are not only present but available and looking exactly as they appear in the statue. The image is contrary to the San's modern realities, their general marginalisation and poverty at odds with the sumptuousness of lodges such as this one. The hunting depicted in the San's pose is given the lie through the postcolonial appropriation of their traditional lands for tourism and the associated big-game hunting which brought about their disenfranchisement; lodges are issued annual licenses for a quota of kills of specific species. Sculpture's heyday in the 1880 s cast the "noble savage" in bronze as a timeless memorial in the same manner as the heroic dead of past wars were immortalised. This statue, although modern, certainly epitomises the genre. The immutable and frozen sculpture, assert the curators of a 1987 exhibition, is "a container that holds its subject sealed off, separated from the world like a photograph in which everything must be enclosed in a square piece of article" (Barrett, 1996, p. 139). This calls up again the first type of photography discussed in the previous section, where "subject as object" is evident.

\section{Conclusions}

This article has attempted to show the effects of unauthorised representations of the San, via a range of publicly accessed visual texts targeted to a specific kind of tourist: those easily hoodwinked through their need to believe in a spiritual innocence lost to the industrialised West. Such representations suggest, through a variety of semiotic devices, including primordial, idealised, eroticised and infantilised imagery, that San are still living their antediluvian lifestyle on ancestral lands, lovingly endorsed by government and enjoying a reflexively beneficial relationship with the corporate world. In fact, this is a sham. It is all the more insidious since the contrived image of primordial naiveté, far from being something to be treasured, is a convenient infantilisation designed to ensure the San do not gain any political traction or entitlement to profits from the CKGR's resources. The vested interests of mining companies and safari 
tourism, where government-issued hunting quotas see lodges making vast fortunes for kills of the "Big Five" (lion, leopard, rhinoceros, elephant, and Cape buffalo). This excludes the San from their ancestral homeland, only to be commodified when needed as part of a safari "Bushman" tour. But the image of the mythical San is still accepted as truth by many, detrimentally affecting their status as neo-colonial victims.

At the same time, San self-representation for tourism consumption in Botswana is incrementally offering alternatives to the deceptive iterations of representation, away from the monolithic and primeval to a more comprehensive and honest drawing of San realities. This heralds the possibility for future for the San in Botswana one in which San groups can express autonomous voices in society and government and in which they themselves decide which representational elements of their ancient culture they wish to incorporate into their modern identities.

\section{Acknowledgments}

I am most grateful to all those who willingly allowed me to photograph them, their businesses, organisations, dwellings and artwork and who participated openly in interviews. Heartfelt thanks are due to my friends and fellow researchers in Botswana and Melbourne, especially Dr. Eureka Mokibelo, Dr. Peter Mwikisa, Dithunya Lekoa and Prof. Kenneth Good. I am much indebted to Prof. Jordan Zlatev and his editorial team, for insightful comments and fastidious copyediting.

\section{References}

Ashcroft, B., Griffiths, G., \& Tiffin, H. (eds) (1995). The post-colonial studies reader. London: Routledge.

Barrett, T. (1996). Criticizing photographs (2 $2^{\text {nd }}$ ed.). California: Mayfield Publishing Co.

Barthes, R. (1979). Camera lucida: Reflections on photography. New York: Hill and Wang.

Barthes, R. (1987 [1957]). Mythologies. New York: Hill \& Wang.

Bolaane, M. (2014). San Cross-Border Cultural Heritage and Identity in Botswana, Namibia and South Africa. African Study Monographs, 35,1, 41-64.

Brown, P. (1999). The Kuru Art Project in visual arts and crafts in Botswana. National Museum Monuments and Art Gallery, Ministry of Labour and Home Affairs, Gaborone, Botswana.

Cook, A. and Sarkin, J. (2009). Who is Indigenous?: Indigenous rights globally, in Africa and among the San in Botswana. Tulane Journal of International \& Comparative Law, 38.

Dada, Coex'ae Qgam, (2011). I don't know why I was created: A biography and portrait. Gaborone: Eggsson Books.

Deacon, J. and Dowson, T., (eds.) 1996, Voices from the Past: Xam Bushmen and the Bleek and Lloyd Collection, Johannesburg: Witwatersrand University Press.

Fanon, F. (1968). The wretched of the earth. New York: Grove Press.

Gillespie, A. (2006). Becoming other: From social interaction to self-reflection. USA: Information Age Publishing Inc.

Gollifer, A. \& Egner, J. (2011). Coex"ae Qgam, (Dada) I don"t know why I was created: A biography and portrait. Gaborone: Eggsson Books.

Gossett, C.W. (1986). The civil service in Botswana. [PhD dissertation]. Stanford University.

Griffiths, G. (1994). The myth of authenticity. In Chris Tiffin \& Alan Lawson (eds). De-scribing empire. London: Routledge.

Groenewald, L. H. (2008). Bushman imagery and its impact on the visual constructs of Pippa Skotnes. [M.A. thesis]. University of South Africa. http://hdl.handle.net/10500/2646

Guenther, M. (1999). Tricksters and trancers: Bushman religion and society. Indiana, USA: Indiana University Press. 
Guenther, M. (2006). Contemporary Bushman Art, Identity Politics and the Primitivism Discourse. In Jacqueline S. Solway (Ed.). The politics of egalitarianism: Theory and practice. 159-188. Oxford: Berghahn Books.

Hiri L., \& Mokibelo, E.B. (2012). Report on the trip to Nyae Nyae Conservancy (Tsumkwe) Namibia. Article presented at San Research Centre (13-18 June, 2012, University of Botswana).

Hitchcock, R.K., \& Brandenburgh, R.L. (1990). Tourism, conservation and culture in the Kalahari Desert, Botswana. Cultural Survival Quarterly. 14, 2, $20-24$.

Hutnyk, J. (2000). Critique of exotica: Music, politics and the culture industry. London: Pluto Press.

Lekoa, D.S. (2007a). Appropriation of culture in tourism: At whose benefits? (Master of Philosophy in Visual Cultural Studies thesis). University of Trømso.

Lekoa, D.S (2007 b). Culture on sale [documentary film]. University of Trømso.

Le Roux, W., \& White, A. (2004). Voices of the San. Cape Town: Kwela Books.

Mishra, V. \& Hodge, B. (2005). What was postcolonialism? New Literary History. 36, 3, 375 402.

Mogalakwe, M. (2003). Botswana: An African miracle or a case of mistaken identity? PULA: Botswana Journal of African Studies. 17, 1, 85-94.

Moynah, M. (2008). Political tourism and its texts. University of Toronto Press.

Mowforth, M., \& Munt, I. (2003). Tourism and sustainability: Development and new tourism in the third world. ( $2^{\text {nd }}$ ed). London: Routledge.

Mulvey, L. (1975). Visual pleasure and narrative cinema. Screen. 16, 3, 6-1.

Paglia, C. (1990). Sexual personae: Art and decadence from Nefertiti to Emily Dickinson. New Haven: Yale University Press.

Prasad, A. (Ed). (2003). Postcolonial theory and organizational analysis: A critical engagement. New York: Palgrave Macmillan.

Radipati, B.D.D.M. (2006). Confronting Procrustean: Indigenous rights under international law. PULA: Botswana Journal of African Studies. 20, 2,162-170.

Salazar, N.B. (2009). Imaged or imagined?: Cultural representations and the "tourismification" of peoples and places, Cahiers d'Etudes Africaines. 49, 49-71.

Salazar, NB., \& Graburn, N. (Eds). (2014). Tourism imaginaries: Anthropological approaches. New York: Berghahn.

Samatar, A. (1999). An African miracle: State and class leadership and colonial legacy in Botswana development. London: Heinemann.

Sherlock, K. (2001). Revisiting the concept of hosts and guests. Tourist Studies. 1, 3, 271-295.

Skotnes, P (Ed.) (1996). Miscast: Negotiating the presence of the Bushmen. Cape Town: University of Cape Town Press.

Skotnes, P. (1996). The thin black line: Diversity and transformation in the Bleek and Lloyd Collection and the paintings of the southern San. In J. Deacon and T. Dowson (Eds.) (1996). Voices from the past: Xam Bushmen and the Bleek and Lloyd Collection. Johannesburg: Witwatersrand University Press.

Smith, M.K., \& Robinson, M. (Eds.) 2006, Cultural tourism in a changing world: Politics, participation and (re)presentation. Channel View Publications.

Sontag, S. (1977). On photography. USA: Picador.

Spurr, D. (1993). The rhetoric of empire: Colonial discourse in journalism, travel writing and imperial administration. London: Duke University Press.

Phillips, RB \& Steiner, CB (eds) 1999, Unpacking Culture: Art and commodity in colonial and postcolonial worlds, University of California Press, Los Angeles.

Steiner, C. (1999). Authenticity, Repetition and Aesthetics. In Phillips, RB \& Steiner, CB (eds) 1999, Unpacking Culture: Art and commodity in colonial and postcolonial worlds, University of California Press, Los Angeles.

Stewart, R., \& Hays, J. (Eds.) (2010). San voices education: Who is going to drive? Kuru Family of Organisations. 
Sylvain, R. (2005). Disorderly development: Globalization and the idea of culture in the Kalahari. American Ethnologist. 32, 3, 354-370.

Tiffin, H. (1987). Post colonial literatures and counter-discourse. Kunapipi. 9, 3, 17-34

Urry, J. (2002). The tourist gaze ( $2^{\text {nd }}$ ed.). California: Sage.

Van der Duim, R., Peters K. \& and Akama, J. (2006). Cultural Tourism in African Communities: A Comparison Between Cultural Manyattas in Kenya and the Cultural Tourism Project in Tanzania. In Smith, M.K., \& Robinson, M. (Eds.) 2006, Cultural tourism in a changing world: Politics, participation and (re)presentation. Channel View Publications.

Wang, N. (1999). Rethinking authenticity in tourism experience. Annals of Tourism Research. 26, 2, 349-370.

Wang, D., Xiang, Z., \& Fesenmaier, D. (2016). Smartphone use in everyday life and travel. Journal of Travel Research. 55, 1, 52-63.

Weinberg, P. (1997). In search of the San. Johannesburg: The Porcupine Press.

\section{Other sources}

Africa Freak. (2011). How to find water in the Kalahari Desert. [Weblog]. http://www.africafreak.com (6 May, 2011)

B \& T Newsletter (2010). www.bandt.com.au (October, 2010)

Kuru D"Kar Trust. (n.d) Ncoa ne khoe ne di huwa ne: San Stories in Naro and English. (D"Kar San Museum / Naro Language Project. Botswana).

Kuru Family of Organisations. Annual Report 2009. www.kuru.co.bw (10 December, 2011).

National Geographic (1999). 178, 6 (15 December 1990).

Stanley, H.M. (1890). In darkest Africa; or, the quest, rescue, and retreat of Emin, Governor of Equatoria. New York: Scribner.

The Wild Source (2009). Kalahari Bushmen build a fire [anonymous weblog]. www.wildernesssafaris.com. (17 June, 2009).

Author's address:

roie.thomas@education.tas.gov.au

Launceston, Tasmania.

About the Author

Roie Thomas is a college teacher in Australia. Her research interests include literary criticism and political resistance. Her doctoral project, The Sweetest Little Buggers: Exploitation and Autonomy in Representations of the Botswana San (Australian Catholic University, 2016) analysed semiotically the mechanisms that perpetuate and challenge the disenfranchisement of a marginalised minority. She is the author of Bushmen in the Tourist Imaginary (Cambridge Scholars Press, 2016). Her current research investigates totalitarianism and dissent in postCastro Cuba. 